\title{
非構造格子の \\ 都市氾濫解析への適用 \\ APPLICATION OF UNSTRUCTURED MESHES \\ TO INUNDATION FLOW ANALYSIS IN URBAN AREA
}

\author{
川池健司 ${ }^{1} \cdot$ 井上和也 $^{2} \cdot$ 戸田圭一 3 \\ Kenji KAWAIKE, Kazuya INOUE and Kei-ichi TODA \\ 1学生員 工修 京都大学大学院 （T606-8501 京都市左京区吉田本町） \\ 2 正会員 工博 京都大学教授 防災研究所 (T611-0011 宇治市五ケ庄) \\ ${ }^{3}$ 正会員 Ph. D. 京都大学助教授 防災研究所（广611-0011 宇治市五ヶ庄）
}

\begin{abstract}
In this study, an inundation flow model is developed using the unstructured meshes, which can divide the computational area into arbitrary shapes of meshes. This model is applied to the basin which was inundated in 1947 due to the levee breakage in Tone River and the numerical results is compared with those of the Cartesian coordinate. Furthermore, this model is used to analyze the effects of small rivers and continuous dikes in the basin. An advanced inundation flow model which has an advantage of considering the influences of linear structures is developed.
\end{abstract}

Key Words : inundation flow model, urban area, unstructured meshes

\section{1.はじめに}

近年，わが国においても毎年のように都市水害が発 生している．様々な要因が複雑にからみ合った都市氾 濫を精度よく予測する解析モデルの開発が，現在必要 とされている.

従来の氾濫解析モデルは, 有限体積法の考え方に基 ブくものが主流で, その最も簡便なものは直交（デカ ルト）座標系を用いたモデル(例えば岩佐ら ${ }^{1)}$ )である. しかしデカルト座標系による矩形格子では, 都市汇濫 に影響を及ぼすと思われるさまざまな要素（例えば, 建造物, 道路, 中小河川など）の影響を取り入れるこ とは困難である. そこで著者らは, 建造物, 道路, 中 小河川などをそれぞれ別々の格子に分割する手法が必 要であると考え, 非構造格子2)を都市汇濫解析に適用 することを試みた。

非構造格子とは, 形状や配列の仕方が不規則な格子 のことをいう（デカルト座標系による格子は非構造格 子の特別な場合と考えることもできる). 非構造格子 を用いる利点は, 領域を任意形状の格子に分割できる こと, さらには解析上の重要性に応じて格子の大きさ を変えることができることなどである. 氾濫水に影響 を及ぼす要素が多数存在し, しかもその形状が複雑な
都市域において非構造格子を汇濫解析に適用すれば, より現実に即した結果が期待できるであろう。

\section{2. 氾濫解析法}

非構造格子に基づく氾濫解析に用いた基礎式は，以 下の浅水方程式である.

$$
\frac{\partial h}{\partial t}+\frac{\partial M}{\partial x}+\frac{\partial N}{\partial y}=0
$$

$\frac{\partial M}{\partial t}+\frac{\partial(u M)}{\partial x}+\frac{\partial(v M)}{\partial y}=-g h \frac{\partial H}{\partial x}-\frac{g n^{2} M \sqrt{u^{2}+v^{2}}}{h^{4 / 3}}$

$\frac{\partial N}{\partial t}+\frac{\partial(u N)}{\partial x}+\frac{\partial(v N)}{\partial y}=-g h \frac{\partial H}{\partial y}-\frac{g n^{2} N \sqrt{u^{2}+v^{2}}}{h^{4 / 3}}$

ここで, $h$ は水深, $H$ は水位, $u, v$ はそれぞれ $x, y$ 方向 の流速, $M, N$ はそれぞれ $x, y$ 方向の流量フラックス, $n$ は粗度係数, $g$ は重力加速度を表す。

これらの未知量は, 図-1に示すような位置で定義 する.すなわち, 全領域に対してまずデカルト座標軸 ( $x$ 軸, $y$ 軸) を設定し，この座標系における各方向の流 速 $(u, v)$, 流量フラックス $(M, N)$ は格子境界（多角形 


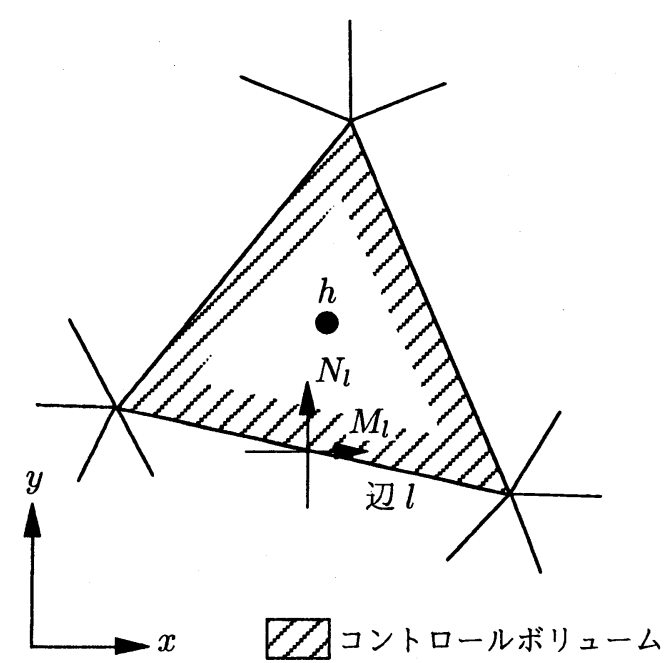

図-1 未知量の定義位置と連続式のコントロールボリューム の辺の中点）で定義し, 水深 $(h)$ は格子の図心（本研 究では多角形の重心を用いる）で定義する。計算は Leap-Frog法を用いて陽的に進める.

まず連続式について，その差分式は以下のものを 用いる.なお，このときのコントロールボリュームは 図-1に示す領域を用いる。

$\frac{h^{n+3}-h^{n+1}}{2 \Delta t}+\frac{1}{A} \sum_{l=1}^{m}\left\{M_{l}^{n+2}(\Delta y)_{l}-N_{l}^{n+2}(\Delta x)_{l}\right\}=0$

ここで, $h$ は格子の水深, $m$ は格子を囲む辺の数, $A$ は コントロールボリューム, すなわち格子の面積である. $M_{l}, N_{l}$ はそれぞれ辺 $l$ 上での $x, y$ 方向の流量フラック スを表し， $(\Delta x)_{l},(\Delta y)_{l}$ は辺 $l$ ての两端の点の $x$ 坐椤, $y$ 座標の差を表す.なお, 上付き添字は時間ステップ である。

運動量式について，図-2に示すように，格子 $i, j に$

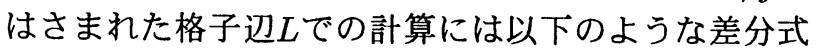
を用いる.

( $x$ 方向)

$$
\begin{aligned}
& \frac{M_{L}^{n+2}-M_{L}^{n}}{2 \Delta t}+M 1+M 2 \\
= & -g \tilde{h}^{n+1}(\nabla H)_{x}-\frac{g n^{2} \frac{M_{L}^{n+2}+M_{L}^{n}}{2} \sqrt{\left(u_{L}^{n}\right)^{2}+\left(v_{L}^{n}\right)^{2}}}{\left(\tilde{h}^{n+1}\right)^{4 / 3}}
\end{aligned}
$$

（y方向）

$$
\begin{aligned}
& \frac{N_{L}^{n+2}-N_{L}^{n}}{2 \Delta t}+N 1+N 2 \\
= & -g \tilde{h}^{n+1}(\nabla H)_{y}-\frac{g n^{2} \frac{N_{L}^{n+2}+N_{L}^{n}}{2} \sqrt{\left(u_{L}^{n}\right)^{2}+\left(v_{L}^{n}\right)^{2}}}{\left(\tilde{h}^{n+1}\right)^{4 / 3}}
\end{aligned}
$$

ここで, $M_{L}, N_{L}$ は格子辺 $L$ 上での $x$ および $y$ 方向の流 量フラックス, $u_{L}, v_{L}$ は格子辺 $L$ 上での $x$ および $y$ 方向 の流速である. $(\nabla H)_{x},(\nabla H)_{y}$ はそれぞれ格子 $i, j$ 間 の水面勾配 $\nabla H$ の $x, y$ 方向成分である. $\tilde{h}$ は格子辺上の 水深であり，図心における水深から補間して求める.

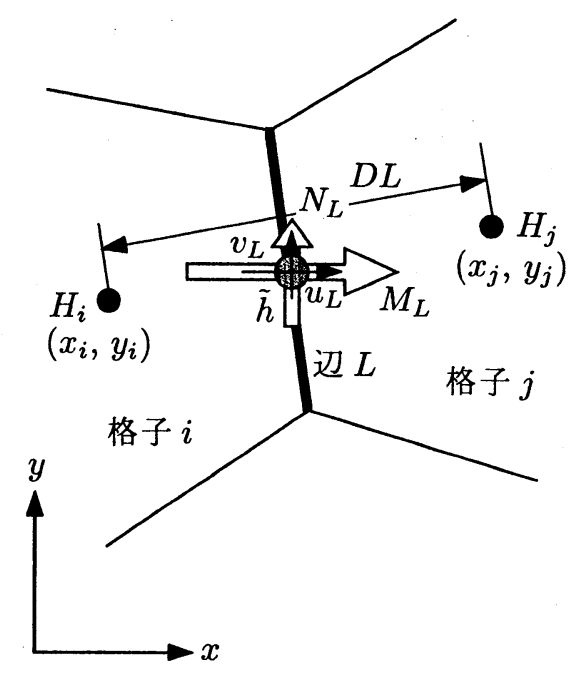

図-2 運動量式の計算に用いる諸量

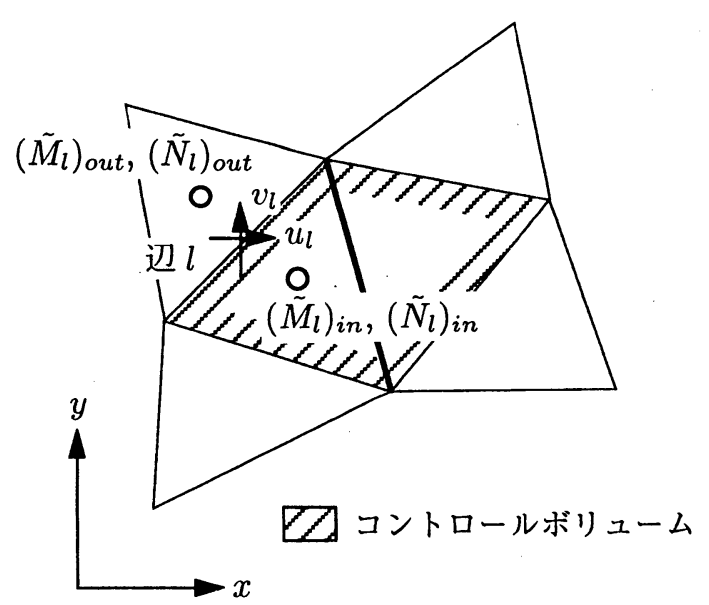

図-3 移流項の計算に用いるコントロールボリューム

$M 1, M 2$ または $N 1, N 2$ は，それぞれ(2), (3)式の移流 項（左辺第2項，第3項）を表しており，図-3に示すよ うなコントロールボリュームを考えて，それぞれ

$$
\begin{aligned}
& M 1+M 2=\frac{1}{A_{c v}} \sum_{l=1}^{m^{\prime}}\left\{\left(u_{l} \tilde{M}_{l}\right)(\Delta y)_{l}-\left(v_{l} \tilde{M}_{l}\right)(\Delta x)_{l}\right\} \\
& N 1+N 2=\frac{1}{A_{c v}} \sum_{l=1}^{m^{\prime}}\left\{\left(u_{l} \tilde{N}_{l}\right)(\Delta y)_{l}-\left(v_{l} \tilde{N}_{l}\right)(\Delta x)_{l}\right\}
\end{aligned}
$$

のように計算する.ここで， $A_{c v}$ はコントロールボリ ュームの面積, $m^{\prime}$ はコントロールボリュームを囲む辺 の数, $u_{l}, v_{l}$ は辺 $l$ 上での流速, $(\Delta x)_{l},(\Delta y)_{l}$ は辺lの両 端の点の $x$ 座標, $y$ 座標の差である. $\tilde{M}, \tilde{N}$ は格子の重 心上の流量フラックスであり, 格子辺上の流量フラッ クスから補間して求める。格子辺上の流速 $\left(u_{l}, v_{l}\right)$ の方

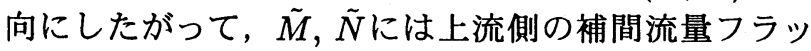
クスを用いることにする。 


\section{3. 利根川流域への適用}

前章で提示した非構造格子による汇濫解析を, 図-4 に示す埼玉県東部・東京都足立区, 葛飾区, 江戸川区 にまたがる利根川流域に適用する。この領域は1947年 （昭和 22 年）カスリーン台風による洪水で甚大な被害 を受けた地域である. 図-5 $\left.\mathbf{5}^{3}\right)$ に当時の浸水実績を示す. この領域を対象とした理由は, 非構造格子が線状の構 造物を考慮するのに適しており,この領域内の中川, 綾瀬川といった中小河川からの汇濫水の排水や, 中小 河川堤防, JR武藏野線などの連続盛土による汇濫水の 遮断の影響をうまく表現できると考えたからである.

本研究では, カスリーン台風時の破堤点を想定破堤 点とし, そこから図-6に示すハイドログラフにした がって氾濫水が流入するとする．このハイドログラフ は, 平面タンクモデル (ポンドモデル) を用いて利根 川破堤による流域の氾濫特性を検討した建設省資料4) によるものである.

まず従来から用いられている汇濫解析手法であるデ カルト座標系による解析結果と比較するため, 中小河 川も連続盛土も考慮しないという簡単な条件で汇濫解 析を行う. 図一7にデカルト座標系と非構造格子の解 析に用いた格子を示す. 非構造格子生成の際には, な るべく格子形状が正三角形または正方形に近くなる ように, またデカルト座標系格子 $(500 \mathrm{~m} \times 500 \mathrm{~m})$ と 極端に大きさが異ならないように配慮した. デカルト 座標系の図には, この領域の地盤高も合わせて示して いる. なお, このときの粗度係数は, 全領域において $n=0.067$ を用いる. 図-8にデカルト座標系による解析 結果を, 図-9に非構造格子による解析結果を示す.両 者を比較すると, 中小河川も連続盛土も考慮しない簡 単な条件下では, ここで提唱した非構造格子による氾 濫解析は従来の手法とほぼ同様の結果をもたらすこと がわかる.しかし，これらを図-5のカスリーン台風来 襲時の汇濫実績と比較すると, 下流端で極端に浸水深 が大きくなっており, しかも氾濫域も実績より西方に 大きく広がっている.これは, 解析では下流端を十分

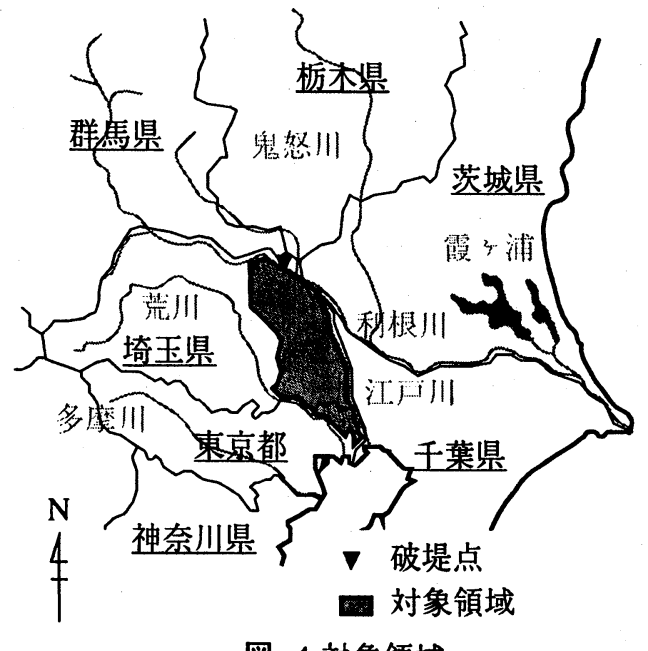

図-4 対象領域
高い直立壁と考え, 氾濫水の排水を全く考慮していな いためであって, 実際には中小河川がらかなりの氾濫 水が排水されると思われる.

つぎに, 非構造格子を用いて中小河川の影響を考慮 した解析を行う. 領域内の格子を, 中小河川格子とそ れ以外の堤内地格子に二分する. 図-10には, 中小河 川として認識した河川を示している.これらの河川格 子は, 周囲の堤内地格子よりも地盤の低い長方形断面 の掘り込み河道として取り扱う. 掘り込み深さは, こ の格子の地盤高に建設省利根川上流工事事務所の資料 を基にした河床の地盤高を与えて決定する.さらに河 川格子と堤内地格子の境界には堤防を考慮して，それ らには同事務所資料に基づいて堤防天端高を与える. また, 河川格子と堤内地格子との間では次の本間の越 流公式5)を適用する. すなわち，隣接する格子のうち 低い方の水位を $H_{l}$, 高い方の水位を $H_{h}$, 堤防天端高 を $H_{0}$ とし, $h_{1}=H_{h}-H_{0}, h_{2}=H_{l}-H_{0}$ とすれば, $h_{1}>0$ のときの流量フラックス $M_{0}$ を,

$h_{2} / h_{1} \leq 2 / 3$ (完全越流）のとき

$$
M_{0}=\mu h_{1} \sqrt{2 g h_{1}}
$$

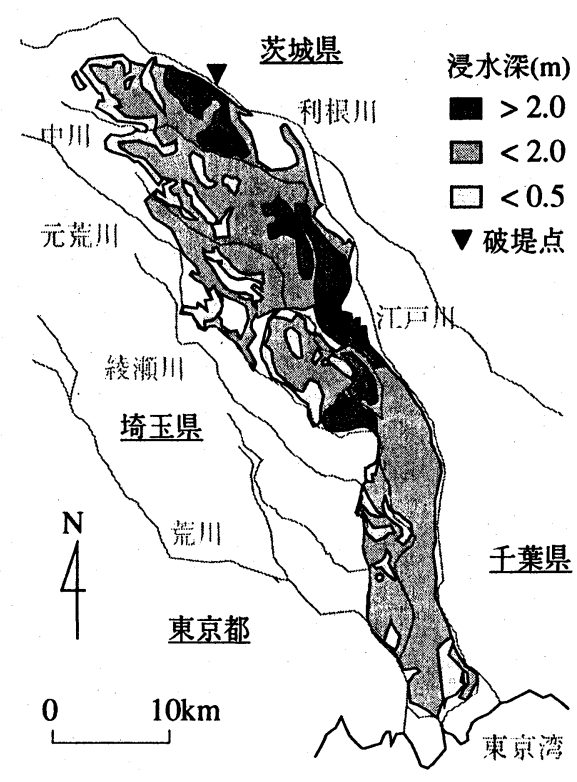

図-5 カスリーン台風実績図 ${ }^{3)}$

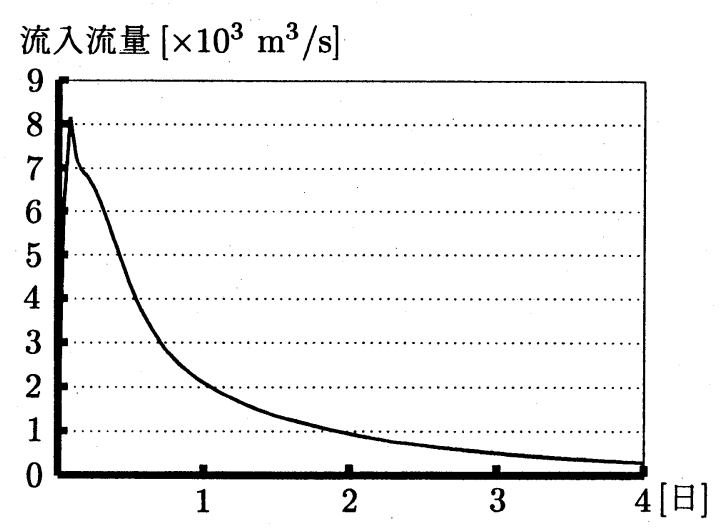

図-6 流入流量ハイドログラフ 

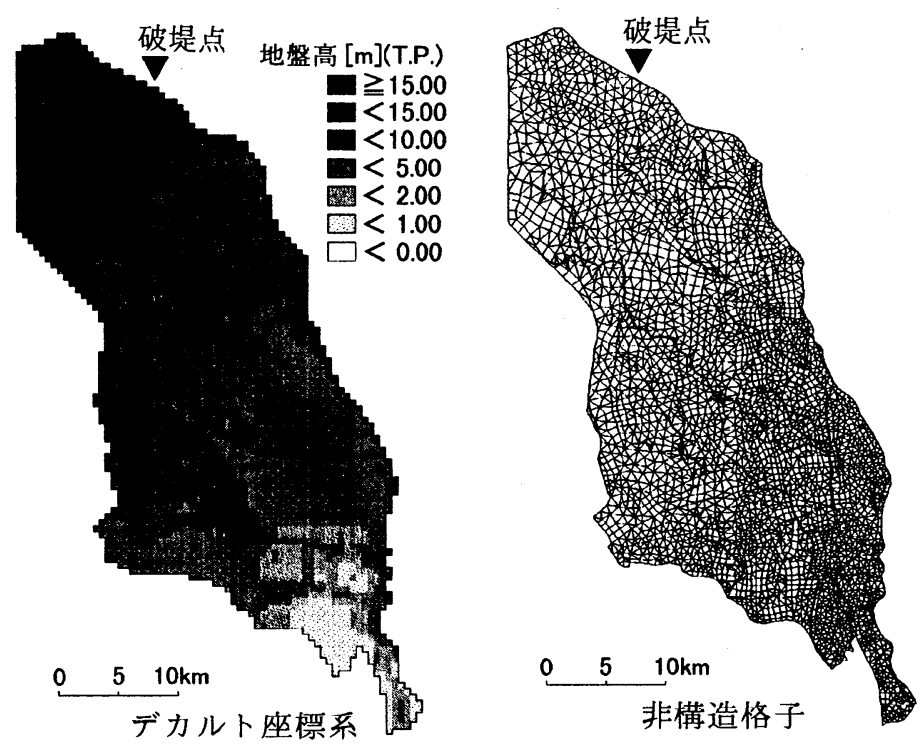

図-7 解析格子と地盤高
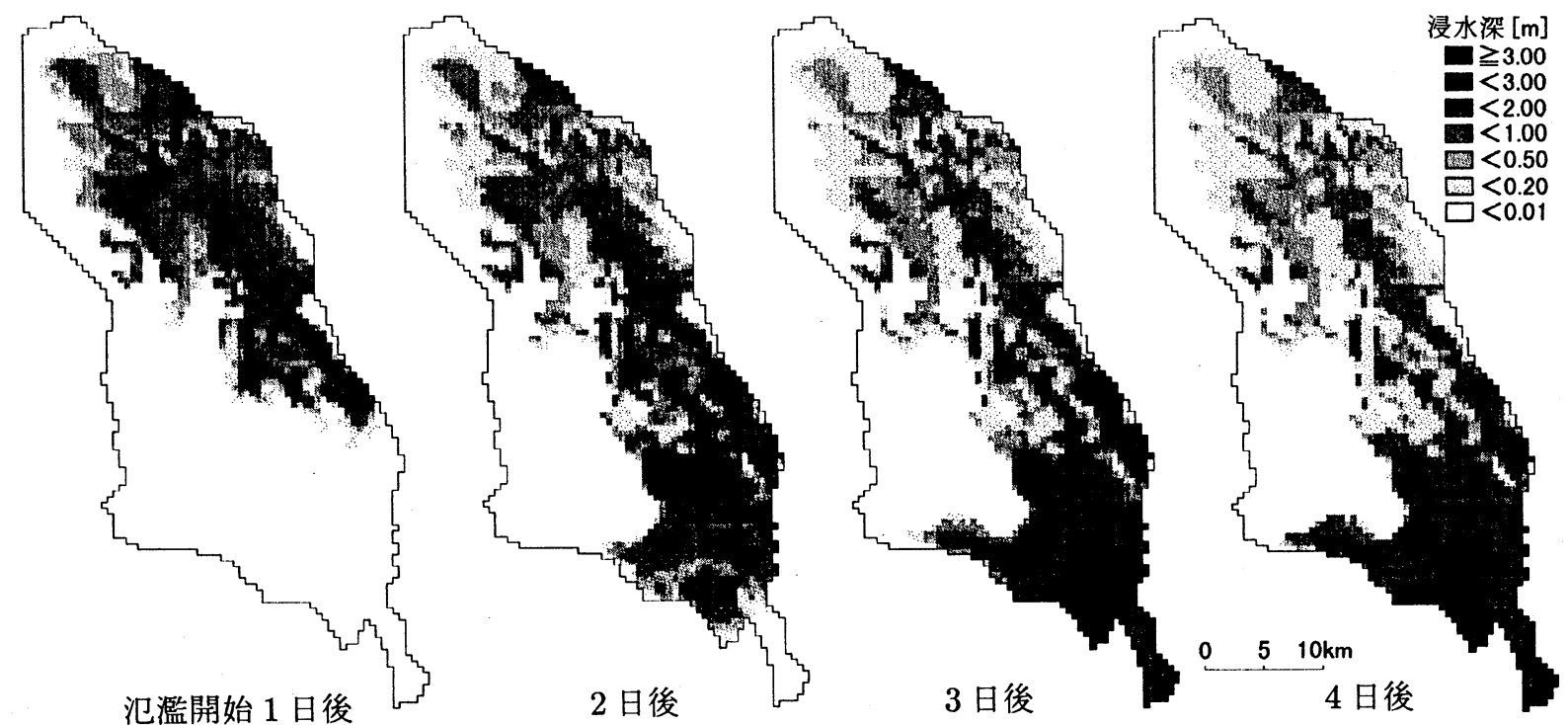

図-8 浸水深の時間変化（デカルト座標系）
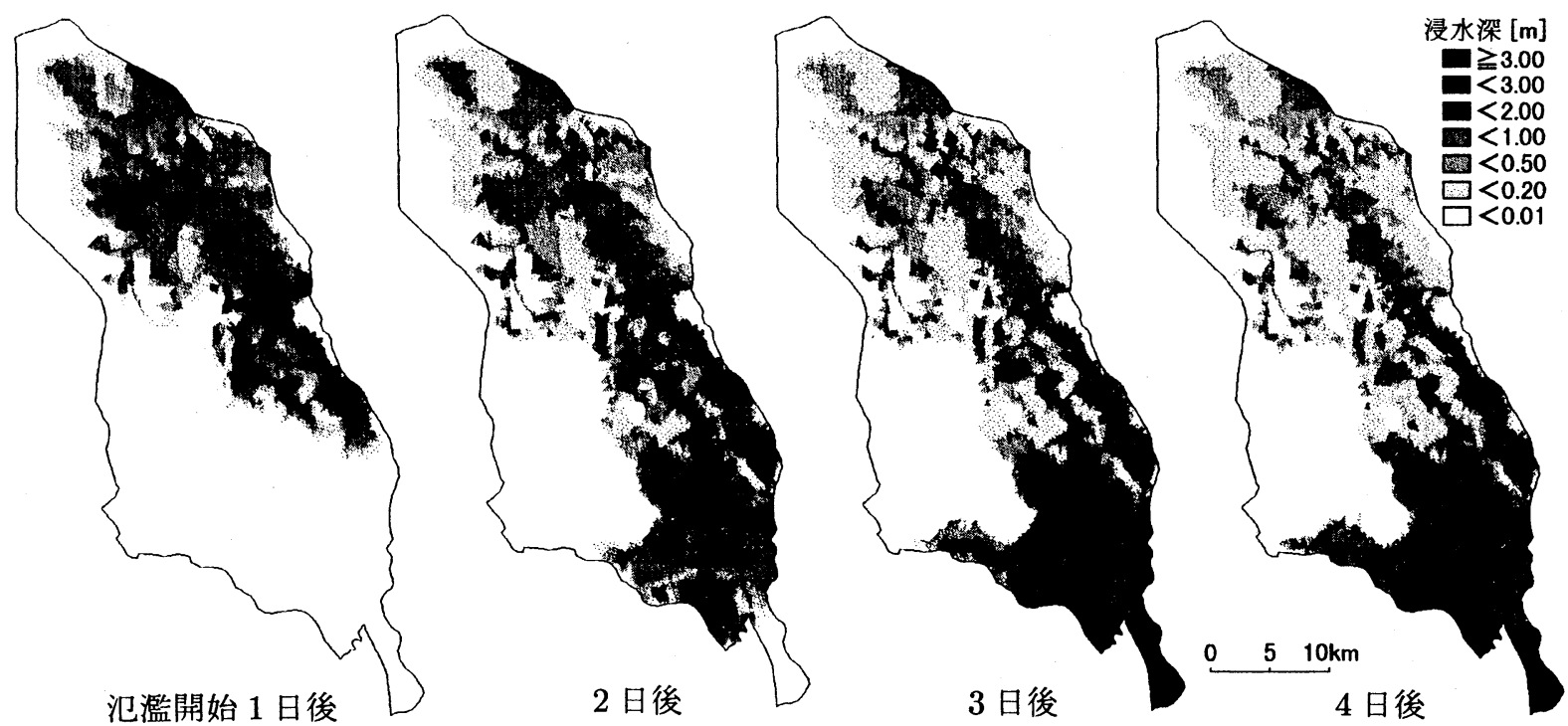

図-9 浸水深の時間変化（非構造格子） 
$h_{2} / h_{1}>2 / 3$ (潜り越流）のとき

$$
M_{0}=\mu^{\prime} h_{2} \sqrt{2 g\left(h_{1}-h_{2}\right)}
$$

で求める.ここで $\mu$ おび $\mu^{\prime}$ は, 完全越流および潜り 越流時の流量係数で, それぞれ0.35および0.91とする. これらの概念図を図-11に示す，粗度係数は，河川格 子では 0.020 , 堤内地格子では 0.067 とする. 下流端の 境界条件は, 中川, 綾瀬川, 新芝川, 三郷放水路の各 下流端の格子において, Manningの公式を用いた等流 条件, すなわち,

$$
Q_{o u t}=v A=\frac{1}{n} R^{2 / 3} I^{1 / 2} \cdot A=\frac{1}{n} \frac{(B h)^{5 / 3}}{(B+2 h)^{2 / 3}} I^{1 / 2}
$$

により, 流出流量が求められる。ここで, $Q_{\text {out }}$ は下流 端から流出する流量, $A$ は断面積, I $I$ 河床勾配, Rは 径深, $B$ は川幅, $h$ は水深である. 氾濫水の排出はこ の河川の下流端でのみ考慮し，それ以外の領域境界は 十分高い直立壁で囲まれているとする．また，これら の河川における初期条件には, 各河川の洪水時流量の 不等流状態を与える. すなわち, この流量を各河川の 上流端の格子に時間的に変化しないとして与え, 下流 端の境界条件を適用して十分長い時間計算した後, 河 川格子の水深が時間的に変化しなくなった状態を定常 状態とみなして, その水深を各河川格子の初期条件と して用いる. なお, この流量は, 汇濫解析中も絶えず 与え続けることとする. 上記のような条件のもとで解 析した結果を, 図-12に示す。この結果を図-9と比較 すると, 下流端付近の浸水深が大きく低減し, さらに 浸水域も綾瀬川の左岸側是防によって堰き止められて いるのがわかる.この解析ケースがカスリーン台風時 の地形に最も近いと考えられるので, 图-12を図-5と 比較すると, 氾濫域は元荒川の左岸側, 綾瀬川の左岸 側までとなっており, 三郷放水路より下流の中川左岸 を除くと，おおむね一致している。これは，中小河川 から氾濫水が排出される影響とその堤防によって氾濫 水が堰き止められている影響がこのモデルによって表 現されたためであろう。

さらに, 中小河川に加えて, 領域内に存在する鉄道 や道路などの連続盛土を考慮した解析を行う. 本研究 では, 図-10に示した, 東北自動車道, 国道16号線, JR武蔵野線の連続盛土を格子境界で認識し, 河川堤 防の取り扱いと同様にこれを越流（横断）する流量フ ラックスを(9), (10)式によって計算する. 解析結果を 図-13に示す. 領域の北西部の東北自動車道の盛土に よって, 氾濫域の拡大が遮断されているのが確認され る. また, 氾濫開始 2 日後以降の浸水深を見ると, JR 武蔵野線の盛土の上流側で浸水深が大きくなっており, ここで氾濫水が一部貯留されているのがわかる. なお, 国道16号線の盛土は, 盛土部分が短いことと, 周囲の 地盤が比較的高いため浸水深が浅いことから, 氾濫状 況にはほとんど影響を与えていないことがわかる.

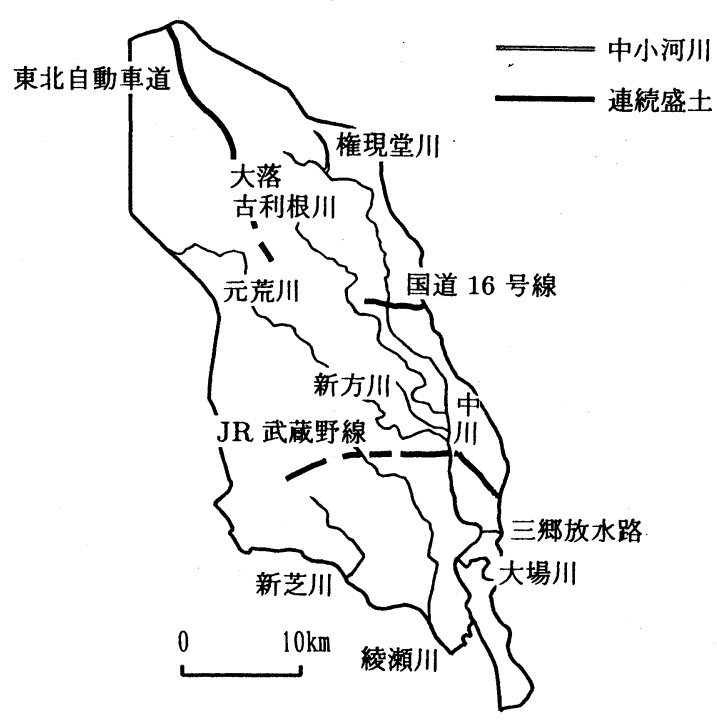

図-10 中小河川と連続盛土
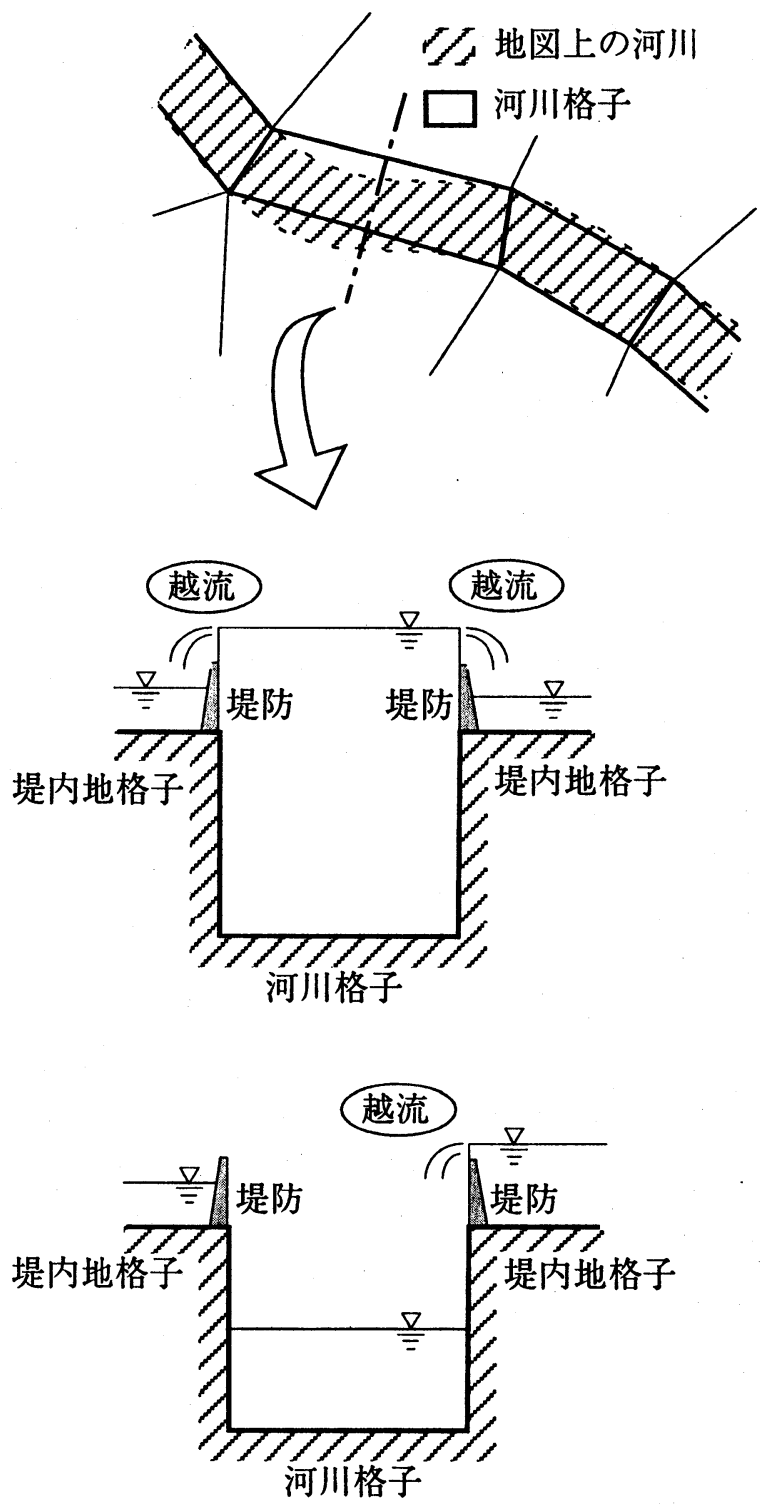

図-11 河川格子の取り扱い 

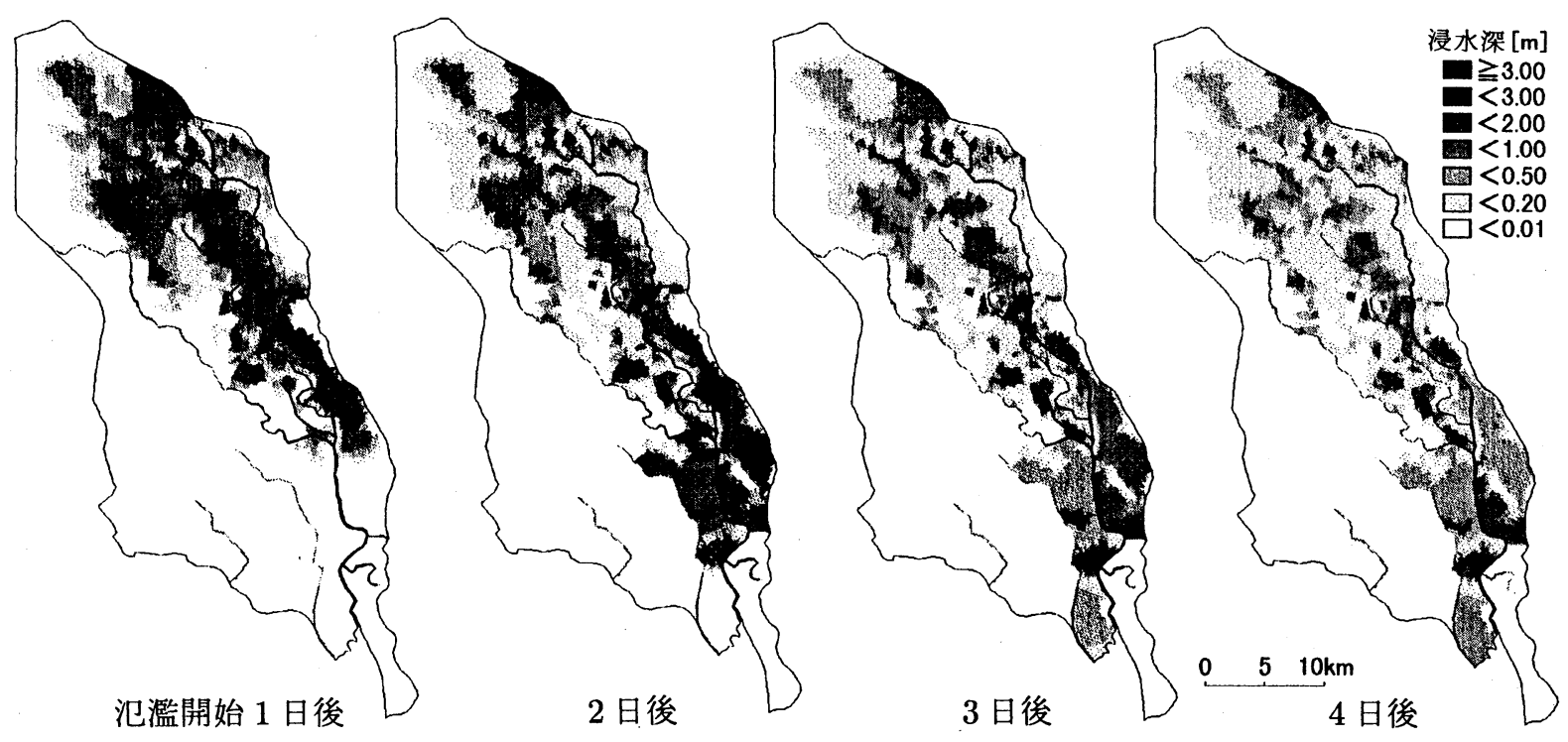

図-12 浸水深の時間変化（中小河川考慮）
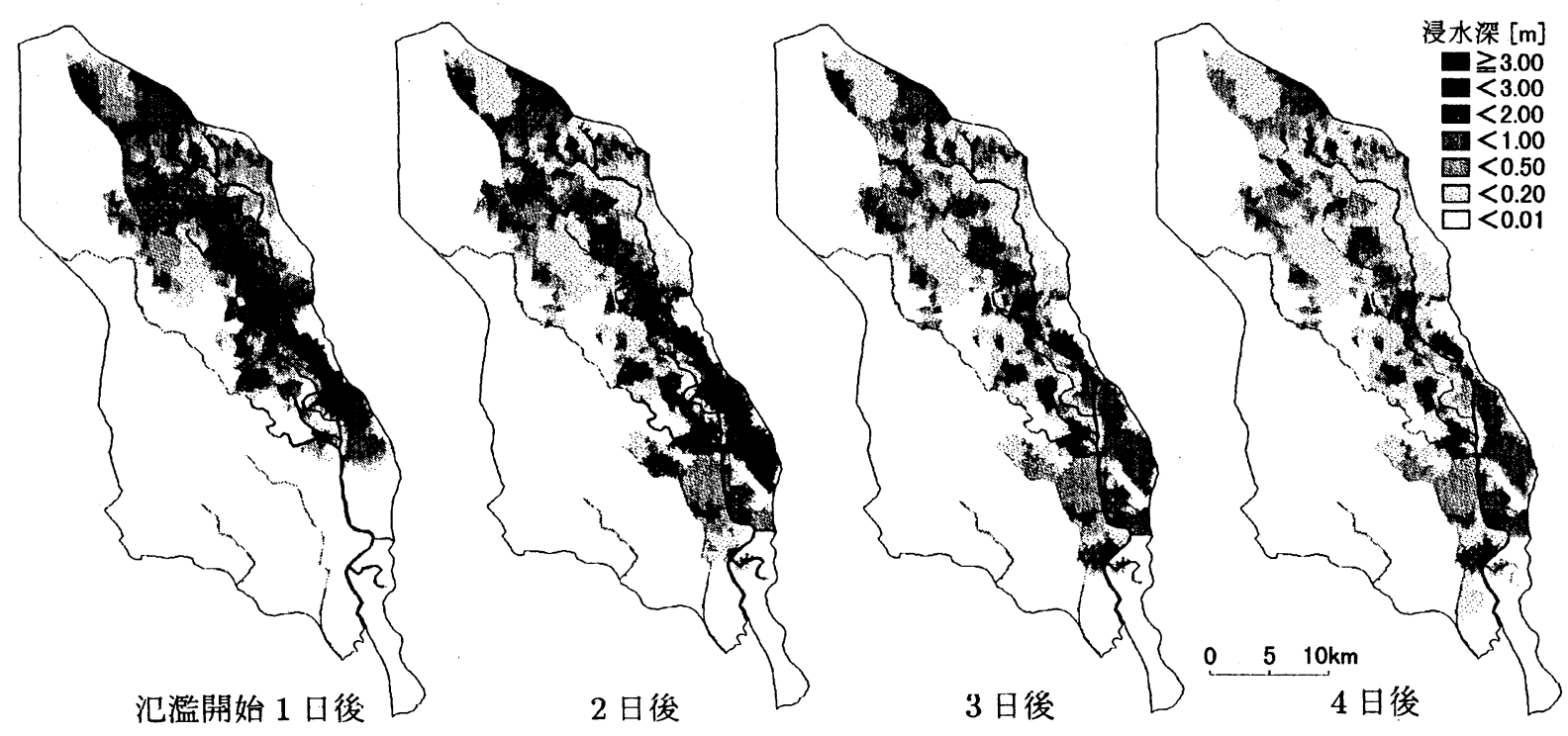

図-13 浸水深の時間変化（中小河川・連続盛土考慮）

\section{4.おわりに}

本研究で提示した非構造格子による汇濫解析法は, 簡単な条件のもとではデカルト座標系による解析とほ ぼ大差ない結果をもたらした. また, 非構造格子は格 子形成の融通性に優れていることから, 線状の構造物 などの対象領域内の微細な地形的特徵を容易にモデル に組み入れることができる.本研究で解析したように 中小河川や連続盛土の影響はこの方法により適切に表 現されており, より高度化した氾濫解析の一手法が提 示できたと考えている.

謝辞 : ご多忙の中, 多くの資料を提供頂きました建設 省利根川上流工事事務所調查課の方々に厚く御礼申し 上げます。

\section{参考文献}

1）岩佐義朗・井上和也 - 水鳥雅文: 汇濫水の水理の数值 解析法, 京都大学防災研究所年報第23号B-2, pp.305$317,1980$.

2）程暁陶・劉如雲 - 顔元亮・楊㖇 : 黄河治理興水資源開 発利用黄河下游稚区水沙運行数学模型及減災措施 的研究, 中国水利水電科学研究院, pp.11-15, 1995.

3）建設省関東地方建設局利根川上流工事事務所 : 利根 川(小冊子), 1995.

4）建設省関東地方建設局利根川上流工事事務所・パシ フィックコンサルタンツ株式会社: 洪水対策調查報告 書, 1995.

5) 土木学会編 : 水理公式集, 昭和 46 年改訂版, p.265, 1971. 